\title{
Morphological Analysis of Derivational Affixes in Brothers Grimm's the Story of Rapunzel
}

\author{
Efrika Siboro \\ Sanata Dharma University, Yogyakarta \\ efrikasiboro6@gmail.com \\ Barli Bram \\ Sanata Dharma University, Yogyakarta \\ barli@usd.ac.id
}

\begin{abstract}
This paper aimed to explore derivational affixes, more specifically the types of derivational affixes and the functions of the derivational affixes in the story of Rapunzel, which was written by the Brothers Grimm. The exploration of the affixes is urgent to conduct because it would assist learners of English in general in enriching their vocabulary items. This study was quantitative descriptive. The researchers collected complex words from the story and analyzed their derivational affixes. Results showed that, first, there existed 33 occurrences of words containing derivational affixes. Four of the 33 words contained three types of prefixes, namely en-, un- and re-, occurring twice, and 29 of the 33 contained suffixes, such as -ful, -ness, -able, -ly, -ing, -ed, -en, -ent, -less, - $y$, ous, and -dom. Second, there were four functions of derivational affixes in the story of Rapunzel, namely noun formation, with 10 occurrences (30.4\%); adjective formation, with eight occurrences (24.2\%); verb formation, with seven occurrences (21.2\%); and adverb formation, with eight occurrences (24.2\%).
\end{abstract}

Keywords: affix, derivational morphology, prefix

\section{INTRODUCTION}

In mastering English, vocabulary plays a crucial role and morphological analyses can be helpful to enrich one's vocabulary items. 
Napa (1991, p. 6) states one of the components of a language is vocabulary and without words the language will not exist. Therefore, vocabulary becomes an important aspect for mastering a language. Morphology is the study of word formation, the words' structure and the process how the words are formed (Meinawati \& Alawiyah, 2018; Jantika, Suganda, Wahya, and Sobarna, 2014; Oz, 2014; Lieber, 2009; Mccarthy, 2002; Aronoff \& Fudeman, 2011; Kusmawardhani, 2018; Rugaiyah, 2018).

In morphology, morphemes are vital factors. Linguistically, a morpheme refers to the smallest shape of word which deals mostly with the grammatical structure comprising of the word (Katamba \& Stonham, 2006; Nunes, Bryant, Pretzlik, \& Hurry, 2006; Bram, 2012; Barrot \& de Leon, 2014; Akbulut, 2017; Halawa, Raflis \& Reni, 2018). From the definition, it can be concluded that a morpheme is the smallest unit of meaning. There are two kinds of morphemes (Lieber, 2009; Luthfiyati, Kholiq, \& Zahroh, 2017; Booij, 2005). The first is free morphemes which can stand alone as words, such as wipe, head, and bracelet. The second is bound morphemes which cannot stand alone, for instance, -un, -ize, and ation. Bound morphemes consist of prefixes and suffixes. If an affix is enclosed before a base, it is called a prefix and if an affix is enclosed after a base, it is called a suffix (Nandito, 2016; Bauer, 2003; Kolanchery, 2015). An affix itself is a bound morpheme when it is enclosed to some other morphemes (Katamba, 1993). In general, affixation, which normally includes prefixation and suffixation, is a productive word formation process in English. Some minor word formation processes, such as backformation and initialism, are categorized as unproductive.

Regarding the enrichment of vocabulary items, there are many strategies that can be implemented, such as reading a novel or short story, listening to music, and watching a movie. In this study, the researchers consider that reading is one of the best ways to enhance vocabulary items. In this paper, the researchers analyzed the short story of Rapunzel, which was written by the Brothers Grimm. The researchers used this story to explore and enrich knowledge about derivational affixes.

Based on the background above, the following two research questions were formulated. First, how many derivational affixes are used in the story of Rapunzel? Second, what are the functions of the derivational affixes in the story of Rapunzel? 


\section{THEORITICAL FRAMEWORK}

There are two kinds of affixes, namely derivational affixes and inflectional affixes (Ford, Davis \& Wilson, 2010; Robinson, 2016). Anindita (2017), Bauer as cited in Zainuddin (2016) and Tariq, Abid, Sultan, Asif, Rafique, and Aleem (2020) argue that derivational and inflectional affixes are different. Derivational affixes can cause a change in the word class or category but inflectional affixes do not change the class of the words. The change in class of derivational affixes will affect the meaning of the words but in inflectional affixes there is no change in the word class. Derivational affixes occur when a root is added by a morpheme that changes the category of the class but sometimes the morpheme does not change the class of the base word, while inflectional affixes only adapt the shape and the meaning of the base word (Payne, 2011 \& Sutarman, 2017). Yule (2010) states there are nine processes of word formation, namely coinage, borrowing, compounding, blending, clipping, backformation, conversion, acronyms, and derivation. Note that in this paper, the researchers would investigate the last word formation process, derivation, which involves prefixes and suffixes.

Previously, Nurjanah, Ramdhaniah, and Efransyah (2018) conducted a study to investigate the types of derivational and inflectional affixes in the text The Ugly Duckling and to describe the affixations that were attached in the derivational and inflectional processes of the text The Ugly Duckling. The results showed that there were 29 words of inflectional processes. The researchers found there were two processes of affixations in the text The Ugly Duckling. In the first process, there were nine words containing suffixes, four derivational processes, and five inflectional processes. In the second process, there was one inflectional process. The second research which was conducted by Sanita (2014) showed that there were eight prefixes and 18 suffixes in the declaration independence. The prefixes that often appeared were un-, dis-, and inwhile suffixes that often occurred were -ion, -tion, ation, -ence, -ance, ment and -er/-or.

\section{RESEARCH METHODOLOGY}

The researchers used quantitative descriptive to identify, describe, analyze and classify the types of derivational affixes in the story of Rapunzel, a well-known German fairy tale which was written by the Brothers Grimm. To analyze the derivational affixes found in story of Rapunzel, the researchers used two resources, namely a primary 
resource and secondary resource. The researchers took the data from the text of the short story of Rapunzel, as the primary source. As for the secondary resource, the researchers used some references to support the analysis. The researchers also referred to some books on morphology in general and on derivational affixes in particular.

The data collection technique was observation and documentation. The researchers took four steps to analyze the collected data. The findings were then described and classified based on their categories. The collected data and analysis results were verified by the researchers by rechecking the data and results to ensure accuracy and validity.

\section{RESULTS AND DISCUSSION}

The following table presents the study results and discussion of the derivational affixes discovered in the story of Rapunzel written by the Brothers Grimm.

Tabel 1. Dervational Affixes in the Story of Rapunzel

\begin{tabular}{|l|l|c|c|c|c|c|}
\hline No. & Word & $\begin{array}{l}\text { Part of } \\
\text { Speech }\end{array}$ & Root & $\begin{array}{l}\text { Part of } \\
\text { Speech }\end{array}$ & $\begin{array}{l}\text { Derivation } \\
\text { al Affixes }\end{array}$ & Note \\
\hline 1 & $\begin{array}{l}\text { beautiful } \\
\text { (p. 115) }\end{array}$ & adj & beauty & noun & -ful & noun maker \\
\hline 2 & $\begin{array}{l}\text { enchantress } \\
\text { (p. 118) }\end{array}$ & noun & enchant & verb & -ress & noun maker \\
\hline 3 & $\begin{array}{l}\text { enchant } \\
\text { (p. 118) }\end{array}$ & verb & chant & noun & en- & verb maker \\
\hline 4 & $\begin{array}{l}\text { miserable } \\
\text { (p. 1111) }\end{array}$ & adj & miser & noun & -able & noun maker \\
\hline 5 & $\begin{array}{l}\text { hastily } \\
\text { (p. 1118) }\end{array}$ & adv & hasty & adj & -ly & adverb \\
maker
\end{tabular}


Efrika Siboro and Barli Bram: Morphological Analysis of Derivational Affixes in Brothers Grimm's the Story of Rapunzel |75

\begin{tabular}{|c|c|c|c|c|c|c|}
\hline No. & Word & $\begin{array}{l}\text { Part of } \\
\text { Speech }\end{array}$ & Root & $\begin{array}{l}\text { Part of } \\
\text { Speech }\end{array}$ & $\begin{array}{l}\text { Derivation } \\
\text { al Affixes }\end{array}$ & Note \\
\hline 14 & $\begin{array}{l}\text { fasten } \\
\text { (p. 2|21) }\end{array}$ & verb & fast & adj & -en & verb maker \\
\hline 15 & $\begin{array}{l}\text { charming } \\
\text { (p. 2l26) }\end{array}$ & adj & charm & noun & ing & $\begin{array}{l}\text { adjective } \\
\text { maker }\end{array}$ \\
\hline 16 & $\begin{array}{l}\text { resound } \\
\text { (p. 2127) }\end{array}$ & verb & sound & verb & re- & verb maker \\
\hline 17 & $\begin{array}{l}\text { singing } \\
\text { (p. 2129) }\end{array}$ & noun & sing & verb & -ing & noun maker \\
\hline 18 & $\begin{array}{l}\text { deeply } \\
\text { (p. 2l29) }\end{array}$ & adv & deep & adj & -ly & $\begin{array}{l}\text { adverb } \\
\text { maker }\end{array}$ \\
\hline 19 & $\begin{array}{l}\text { Immediately } \\
\text { (p. 3/12) }\end{array}$ & adv & immediate & adj & -ly & $\begin{array}{l}\text { adverb } \\
\text { maker }\end{array}$ \\
\hline 20 & $\begin{array}{l}\text { frightened } \\
\text { (p. 3|13) }\end{array}$ & adj & frighten & verb & -ed & $\begin{array}{l}\text { adjective } \\
\text { maker }\end{array}$ \\
\hline 21 & $\begin{array}{l}\text { frighten } \\
\text { (p. 3|13) }\end{array}$ & verb & fright & noun & -en & verb maker \\
\hline 22 & $\begin{array}{l}\text { willingly } \\
\text { (p. 3/21) }\end{array}$ & adv & willing & adj & -ly & adverb maker \\
\hline 23 & $\begin{array}{l}\text { remarked } \\
\text { (p. } 3 / 26)\end{array}$ & verb & mark & verb & re- & verb maker \\
\hline 24 & $\begin{array}{l}\text { lovely } \\
\text { (p. 4|6) } \\
\end{array}$ & adj & love & verb & $-1 y$ & $\begin{array}{l}\text { adjective } \\
\text { maker }\end{array}$ \\
\hline 25 & $\begin{array}{l}\text { pitiless } \\
\text { (p. 4l7) }\end{array}$ & adj & pity & noun & -less & $\begin{array}{l}\text { adjective } \\
\text { maker }\end{array}$ \\
\hline 26 & finding & noun & find & verb & -ing & noun maker \\
\hline 27 & $\begin{array}{l}\text { misery } \\
\text { (p. } 4 \mid 8)\end{array}$ & noun & miser & noun & $-y$ & noun maker \\
\hline 28 & $\begin{array}{l}\text { venomous } \\
\text { (p. 4l16) }\end{array}$ & adj & venom & noun & -ous & $\begin{array}{l}\text { adjective } \\
\text { maker }\end{array}$ \\
\hline 29 & $\begin{array}{l}\text { mockingly } \\
\text { (p. 4l17) }\end{array}$ & adv & mocking & adj & $-1 y$ & adverb maker \\
\hline 30 & $\begin{array}{l}\text { wretchedness } \\
\text { (p. 4l29) }\end{array}$ & noun & wretched & adj & -ness & noun maker \\
\hline 31 & $\begin{array}{l}\text { kingdom } \\
\text { (p. } 4 \mid 33)\end{array}$ & noun & king & noun & -dom & noun maker \\
\hline 32 & $\begin{array}{l}\text { joyfully } \\
\text { (p. } 4 \mid 33 \text { ) }\end{array}$ & adv & joyful & adj & -ly & $\begin{array}{l}\text { adverb } \\
\text { maker }\end{array}$ \\
\hline 33 & $\begin{array}{l}\text { contented } \\
\text { (p. 4l35) }\end{array}$ & adj & content & noun & -ed & $\begin{array}{l}\text { adjective } \\
\text { maker }\end{array}$ \\
\hline
\end{tabular}

Table 1 above shows a summary of the 33 occurrences derivational affixes in the story of Rapunzel. In this context, the researchers explored a word formation process called derivation. The other eight processes, as proposed by Yule (2010), namely coinage, borrowing, compounding, blending, clipping, backformation, conversion and acronyms were excluded. In the following, the derivational affixes and their functions are discussed. 


\section{Derivational affixes found in the story of Rapunzel}

\section{a. Prefix}

A prefix is an affix which is placed before the base of a word, for example, un-, dis- and en- in the words unhappy, disappear, and enclose. In the short story of Rapunzel, there existed two derivational prefixes (and a derivational suffix), namely un- and re- (and -en). The explanations are as follows:

1) Prefix un-

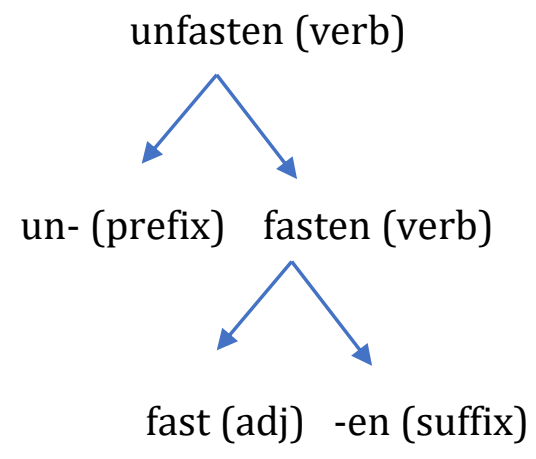

Unfasten (in unfastened) is formed through a derivational process, which consists of fast as a free morpheme and -en and un- as bound morphemes. Note that the suffix -ed in this case is an inflectional affix since it marks the past tense form of the verb, namely unfastened.

2) Prefix re-

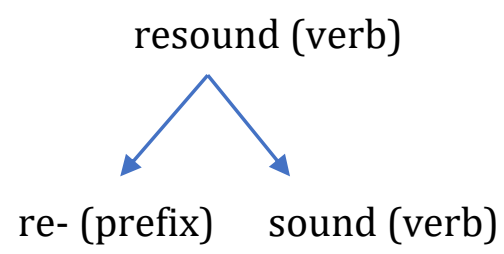

Resound is formed through a derivational process which consists of sound as a free morpheme and re- as a bound morpheme.

b. Suffix

Morphologically, a suffix is an affix which is enclosed after the base of a word, as in happiness, weakness, government, and helpful. In the short story of Rapunzel, the researchers identified several suffixes, 
such as -ful, -ress, -able, -ly, -ing, -ed, -ent, -less, -y, -ous, -ness, -dom and -en.

1) Suffix -ful

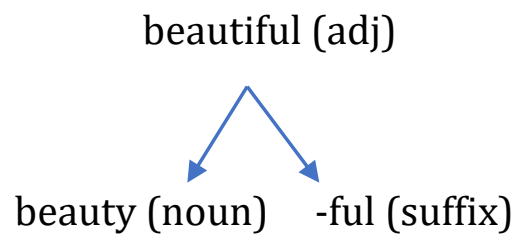

The word beautiful consists of two morphemes, namely beauty as free morpheme and -ful as bound morpheme. The suffix -ful changes the category of the base word from a noun into adjective.

2) Suffix -ress

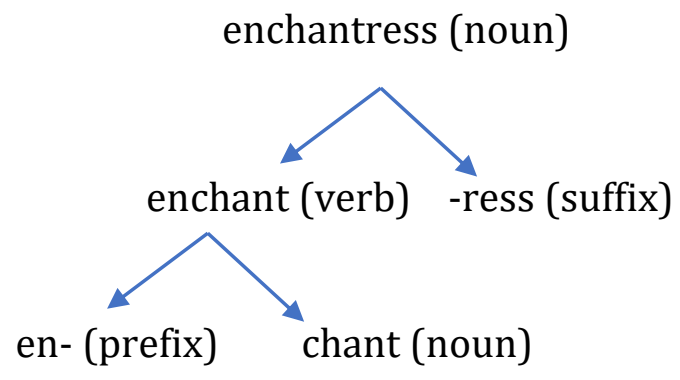

The word enchantress consists of three morphemes, namely chant as free morpheme and en- and -ress as bound morphemes. An enchantress is a woman who has a magical power.

3) Suffix -able

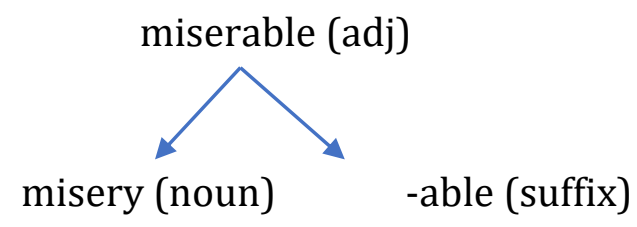

The word miserable consists of two morphemes, namely misery as free morpheme and -able as bound morpheme. 
4) Suffix -ly

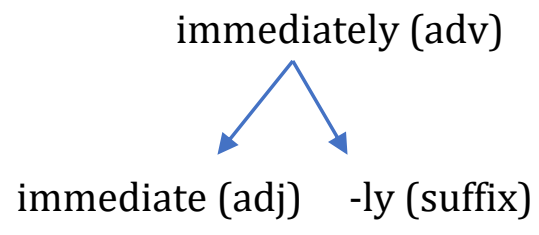

The word immediately consists of two morphemesm namely immediate as free morpheme and -ly as bound morpheme.

5) Suffix -ing

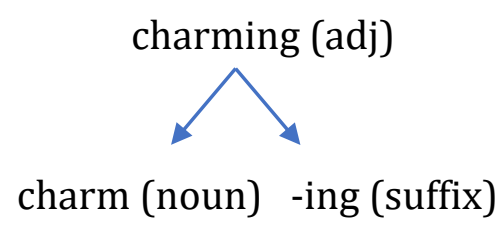

The word charming consists of two morphemes, that is charm as free morpheme and -ing as bound morpheme.

6) Suffixes -ed and -en

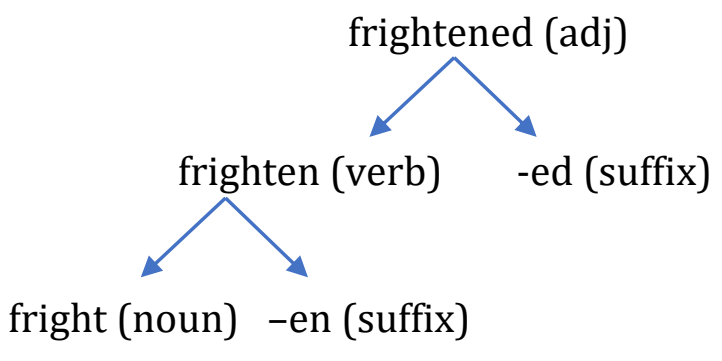

The word frightened consists of three morphemes, namely fright as free morpheme and -en and -ed as bound morphemes.

7) Suffix -ent

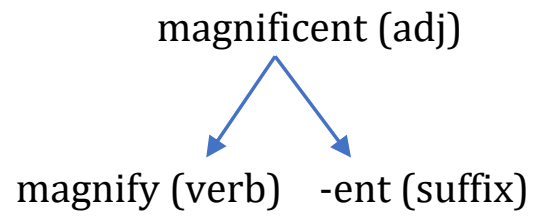


The word magnificent consists of two morphemes, that is magnify as free morpheme and -ent as bound morpheme. Note that spelling adjustments occur in this word.

8) Suffix -less

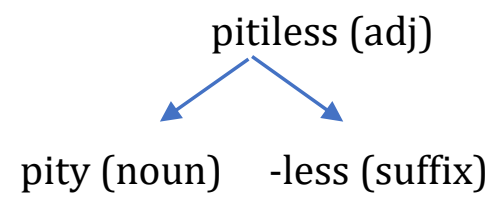

The word pitiless consists of two morphemes, namely pity as free morpheme and -less as bound morpheme. The suffix -less not only changes the category of the base word but also the meaning.

9) Suffix - $y$

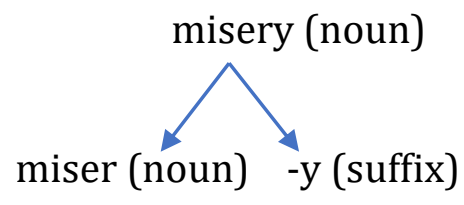

The word misery consists of two morphemes. They are miser as free morpheme and $-y$ as bound morpheme.

10) Suffix -ous

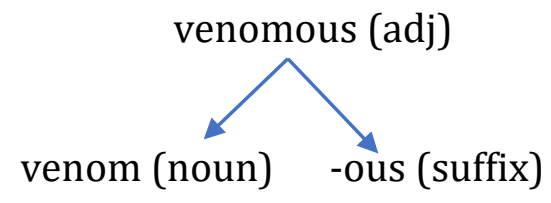

The word venomous consists of two morphemes. They are venom as free morpheme and -ous as bound morpheme. The suffix -ous not only changes the category of the base word but also the meaning. The suffix -ous changes the category of the base word from noun into adjective. The combination of venom and -ous has changed the meaning of the base word. 
Venom is a poison that is produced by an animal and venomous means full of poison.

11)Suffix -ness

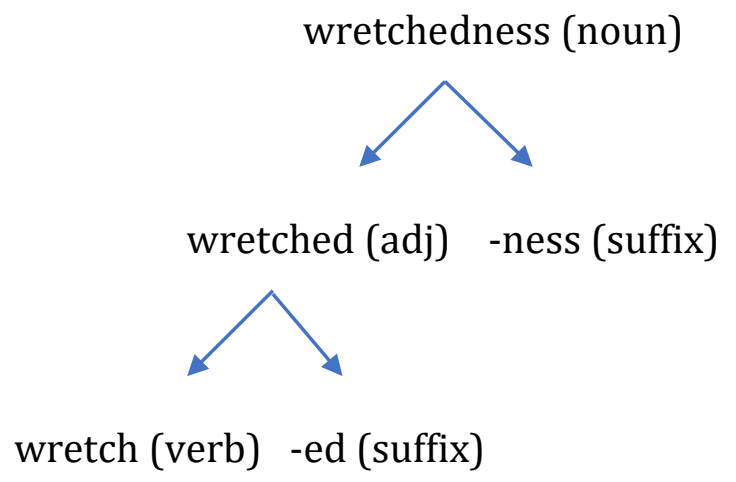

The word wretchedness consists of three morphemes, namely wretch as free morpheme and -ed and -ness as bound morphemes.

12)Suffix -dom

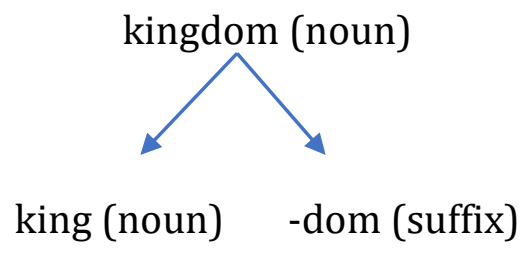

The word kimgdom consists of two morphemes, namely king as free morpheme and -dom as bound morpheme. Kingdom is combined with a derivational suffix because the suffix -dom changes the meaning of the base word but it does not affect the category of the word. The word king means a male who holds a position in a country while kingdom is an area that is controlled by the king. 
13)Suffixes -ful and -ly

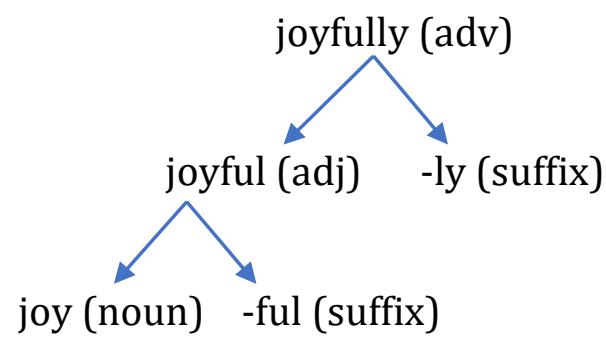

The word joyfully consists of three morphemes, that is joy as free morpheme, and ful, and -ness as bound morphemes. The suffixes - fu and -ly change the category of the base word from a noun into an adjective and then an adverb.

\section{Function of derivational affixes in found in the short story of Rapunzel}

After analyzing the derivational affixes, the researchers identified four functions of derivational affixes in the story of Rapunzel, as presented in Table 2.

\section{Table 2.}

Function and Frequency of Derivational Affixes

\begin{tabular}{clcc}
\hline No. & Function of Affix & Frequency & Percentage \\
\hline 1. & noun formation & 8 & 24.2 \\
2. & adjective formation & 10 & 30.4 \\
3. & verb formation & 7 & 21.2 \\
4. & adverb maker & 8 & 24.2 \\
\hline \multicolumn{2}{r}{ Total } & 33 & 100 \\
\hline
\end{tabular}

Based on the table above, the most productive category is the adjective formation, occurring 10 times or 30.4 per cent, and the least frequent category is the verb formation, occurring seven times, representing 21.2 per cent of the entire data. The adjective formation appeared the most frequent because the story of Rapunzel carries many descriptions of nouns, and accordingly, adjectives are used to modify the 
nouns. The verb formation is the least frequent because the verbs in the story of Rapunzel are mostly in the form of past tense, and therefore, these past tense verbs are not classified as derivation, but inflection, which is beyond the focus of this paper.

\section{CONCLUSION}

Based on the study results, in the short story of Rapunzel, there existed 33 occurrences of words which contain prefixes and suffixes. Four occurrences of words with prefixes en-, un- and re-were enchanted, unfastened, resound and remarked. Words containing suffixes occurred 29 times, such as -ful, -ress, -able, -ly, -ing, -ed, -en, -ent, -less, -y, -ous, -est, -ness, and -dom. In this study, the researchers found that most derivational affixes change the category of word or part of speech and the meaning. There existed four functions of derivational affixes in the short story of Rapunzel, namely noun formation, adjective formation, verb formation and adverb maker. With seven occurrences, the verb formation was the least productive and with 10 occurrences, the adjective formation appeared to be the most productive. Each with eight occurrences, the noun formation and the adverb formation were classified as semi productive.

\section{REFERENCES}

Akbulut, F. D. A. (2017). Effects of morphological awareness on second language vocabulary knowledge. Journal of Language and Linguistic Studies, 13(1), 10-26.

Anndita, W.K. (2017). The acquisition of Indonesian affixation on inflection and derivation of two to five years old children. The First English Language and Literature International Conference (ELLiC), 1, 335-341.

Aronoff, M., \& Fudeman, K. (2011). What is morphology? (2nd ed). Chichester: Wiley-Blackwell

Barrot, J., \& de Leon, K. (2014). Accuracy order of the grammatical morphemes in the oral production of preschool pupils. Indonesian Journal of Applied Linguistics, 3(2), 63-76.

Bauer, L. (2003). Introducing linguistic morphology. Edinburgh: 
Edinburgh University Press.

Booij, G. (2005). The grammar of words. Oxford: Oxford University Press.

Bram, B. (2012). Three models of English morphology. LLT Journal: A Journal on Language and Language Teaching, 15(1), 179-185. Retrieved from https://ejournal.usd.ac.id/index.php/LLT/article/view/316

Ford, M. A., Davis, M. H., \& Marslen-Wilson, W. D. (2010). Derivational morphology and base morpheme frequency. Journal of Memory and Language, 63(1), 117-130.

Halawa, A., Raflis, \& Reni, F. (2018). An analysis of derivational and inflectional morphemes. Jurnal Ilmiah Langue and Parole, 1(1), 132-144.

Jantika, A. W., Suganda, D., Wahya, W., \& Sobarna, C. (2014). Typical morphology system of language advertising of cellular services. International Journal of Linguistics, 6(3), 181-197.

Katamba, F. (1993). Modern linguistic: Morphology. New York: St. Martin's Press.

Katamba, F., \& Stonham, J. (2006). Morphology (2nd ed). New York: Palgrave Macmillan.

Kolanchery, G. (2015). Analytical components of morphology. Global English-Oriented Research Journal, 1(1), 161-166.

Kusmawardhani, P. (2018). The error analysis of derivational morphology in EFL's English narrative composition. International Journal of Language Education, 2(1), 22-30.

Lieber, R. (2009). Introducing morphology. New York: Cambridge University Press.

Luthfiyati, D., Kholiq, A., \& Zahroh, I. N. matus. (2017). The analysis of word formation processes in the Jakarta Post website. Journal of Linguistics, English Education and Art, 1(1), 30-36.

Mccarthy, C. A. (2002). An introduction to English morphology: Words and their structure. Bodmin: Edinburgh University Press.

Meinawati, S \& Alawiyah, S. (2018). Affixation in the script song lyric "Hall of Fame". Research and Innovation in Language Learning, 1(2), 89-100. 
Nandito, I. K. (2016). Derivational and inflectional morphemes. International Research Journal of Engineering, IT \& Scientific Research, 2(1), 22-29.

Napa, P. A. (1991). Vocabulary developing of contemporary English. London: Longman Group, Ltd.

Nunes, T., Bryant, P., Pretzlik, U., \& Hurry, J. (2006). improving literacy by teaching morphmes. New York: Routledge.

Nurjanah, S. Y., Ramdhaniah, A., \& Efransyah, M. (2018). Affixation of derivational and inflectional process in narrative text entitled the Ugly Duckling. Professional Journal of English Education, 01(03), 318.

Öz, H. (2014). Morphology and implications for English language teaching. In A. Saricoban (Ed.), Linguistics for English language teaching studies (pp. 83-120). Ankara: Ani Publishing.

Payne, T. E. (2011). Understanding English grammar. New York: Cambridge University Press.

Rugaiyah, R. (2018). Derivational and inflectional morphemes: A morphological analisis. Journal of English for Academic, 5(2), 7386.

Sanita, J. (2014). The analysis of historical origin and productiveness of derivational affixes in the declaration of independence of America (1776). Journal of Language and Literature, 14(2), 155.

Sutarman, S. (2017). Derivational and Inflectional Affixation in MenuMeni Dialect of Sasak Language. Journal on Language and Literature, 4(1), 121-136.

Tariq, T. R., Abid. M., Sultan, B., Asif, M., Rafique, N., \& Aleem, S. (2020). An analysis of derivational and inflectional morphemes. International Journal of Linguistics, 12(1), 83-91.

Yule, G. (2010). The study of language. New York: Cambridge University Press.

Zainuddin, Z. (2016). A study on derivational affixes of Indonesian nounformation in newspaper editorials: A semantic perspective. International Journal of English Linguistics, 6(3), 148-155. 